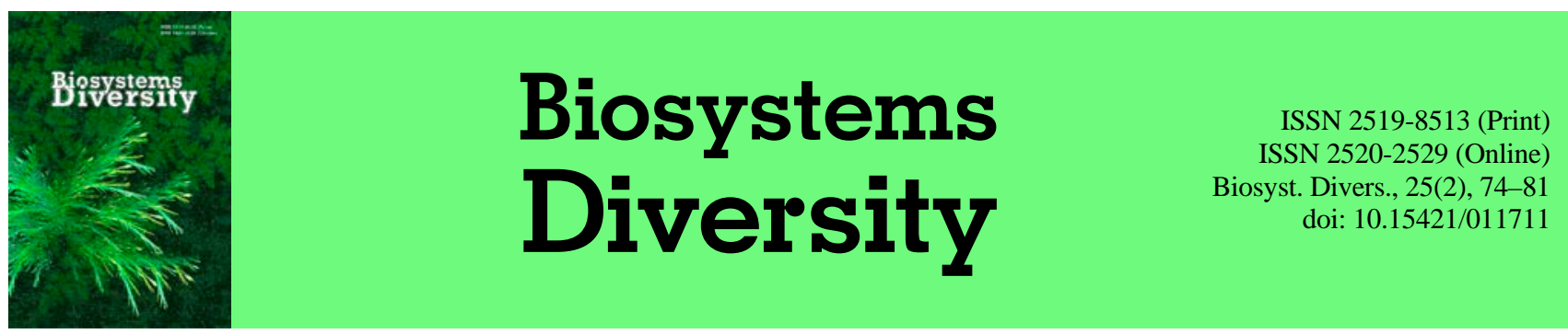

\title{
The effect of active forms of silicon on the biomass of agricultural crops during their growth period on technogenically altered soils of the Nikopol Manganese Ore Basin
}

\author{
I. V. Wagner, V. I. Chorna \\ Dnipro State Agrarian-Economic University, Dnipro, Ukraine
}

Article info

Received 12.04.2017

Received in revised form 07.05.2017

Accepted 08.05.2017

Dnipro State Agrarian-Economic University,Voroshilov Str., 25, Dnipro, 49027, Ukraine.

Tel.: +38-097-268-38-71.

E-mail: wagner_ignatiy@mail.ru
Wagner, I. V., \& Chorna, V. I. (2017). The effect of active forms of silicon on the biomass of agricultural crops during their growth period on technogenically altered soils of the Nikopol Manganese Ore Basin. Biosystems Diversity, 25(2), 74-81. doi:10.15421/011711

The problem of recovery of technogenically affected soils remains unsolved. Silicon which moves in the "soil plant" system has been insufficiently studied, though this element takes part in many processes. For assessing the role of silicon compounds, we selected samples of technogenically affected soils of different types in the territory of the research station for land reclamation of Dnipro State Agrarian-Economic University in the Nikopol Manganese Ore Basin. We conducted a vegetative experiment and a series of laboratory tests with adding $\mathrm{SiO}_{2}$. We chose the following crops: buckwheat (Fagopyrum esculentum Moench, 1794), vetch (Vicia sativa Linnaeus, 1753) and sunflower (Helianthus annuus Linnaeus, 1753). The $\mathrm{pH}$ of the studied soils fluctuated between 7.1 to 7.8 . The content of available nitrogen and phosphorus in the soils was low, except the content of phosphorus in pedozems. We analyzed 240 samples of plants and measured their biomass. Vetch grew best on sod-lithogenous soils on forest-like lomy soils, buckwheat and sunflower - on sod-lithogenous soils on grey-green clays. The variant of experiment with $0.2 \%$ solution of $\mathrm{SiO}_{2}$ was most the efficient during growing all chosen crops on all types of studied soils. After adding amphoteric silicon, the best biomass indicators of vetch and buckwheat were observed on sod-lithogenous soils on forest-like loam, and indicators for sunflower - on sod-lithogenous soils on grey-green clays. After using $0.3 \%$ and $0.4 \%$ solution of $\mathrm{SiO}_{2}$, a gel film forms, which the seeds have no energy to penetrate and run out. Thus it slows the plant's growth. An exception was an experiment with pedozems with adding $0.4 \%$ solution of $\mathrm{SiO}_{2}$, when the biomass of vetch was 1.5 times greater than in the experiment with $0.2 \%$ solution. We observed no similar positive effect in other variants of the experiment. All chosen crops on technogenically affected soils reacted to addition of silicon compounds by increasing biomass under the influence of $\mathrm{SiO}_{2}$ solutions with concentration higher than $0.2 \%$. Possibly, the increase in biomass during the first 14 days is connected with adsorbing activity of silicon, which retains water and accelerates the development of plants. Even with low content of available nitrogen and phosphorum, addition of silicon compounds increased the biomass of plants by two-four times, therefore silicon in this case is a limiting factor.

\section{Вплив активних форм кремнію на біомасу сільськогосподарських культур під час їх вирощування на техногенно порушених грунтах Нікопольського марганцеворудного басейну}

\author{
I. В. Вагнер, В. I. Чорна \\ Дніпровський державний аграрно-економічний університет, Дніпро, Украӥна
}

Проблема відновлення техногенно порушених грунтів донині залишається невирішеною. Рухомий кремній у системі «грунт рослина» маловивчений, але цей елемент бере участь у багатьох процесах. Для встановлення ролі кремнієвих сполук відібрано зразки техногенно порушених грунтів різних типів на ділянках науково-дослідного стаціонару з рекультивації земель Дніпровського державного аграрно-економічного університету у Нікопольському марганцеворудному басейні. Закладено вегетаційний експеримент і проведено серії лабораторних дослідів із додаванням $\mathrm{SiO}_{2}$. Серед культур обрано гречку (Fagopyrum esculentum Moench, 1794), вику (Vicia sativa Linnaeus, 1753) і соняшник (Helianthus annuus Linnaeus, 1753). pH досліджуваних грунтів коливається від 7,1 до 7,8. Вміст доступного азоту та фосфору у грунтах низький, крім вмісту фосфору у педоземах. Проаналізовано 240 зразків рослин, установлено їх біомасу. Вика краще проявила себе на дерново-літогенних грунтах на лесоподібному суглинку, а гречка та соняшник - на дерново-літогенних грунтах на сірозелених глинах. Варіант експерименту з $0,2 \%$ розчином $\mathrm{SiO}_{2}$ виявився найефективнішим під час вирощування всіх обраних культур на всіх типах досліджених грунтів. При додаванні амфотерного кремнію найкращі показники біомаси вики та гречки зафіксовано на дерноволітогенних грунтах на лесоподібному суглинку, а соняшнику - на дерново-літогенних грунтах на сіро-зелених глинах. За час використання $0,3 \%$ та $0,4 \%$ розчину $\mathrm{SiO}_{2}$ виникає гелеподібна плівка, на подолання якої у насіння не вистачає енергії проростання, розвиток рослини 
уповільнюється. Винятком став експеримент на педоземах із додаванням 0,4\% розчину $\mathrm{SiO}_{2}$, за якого біомаса вики була більшою в 1,5 раза, ніж в експерименті з 0,2\% розчином. В інших варіантах такий позитивний ефект не прослідковувався. Всі обрані культури на техногенно порушених грунтах добре реагують на внесення кремнієвих сполук збільшенням біомаси за дії розчинів $\mathrm{SiO} 2$ iз концентрацією понад 0,2\%. Можливо, збільшення біомаси у перші 14 діб пов’язане з адсорбувальною дією кремнію, який утримує воду та прискорює розвиток рослини. Навіть за низького вмісту доступного азоту та фосфору внесення кремнієвих сполук збільшувало біомасу рослини удвічі-вчетверо, тому кремній у даному випадку - лімітувальний фактор.

Ключові слова: кремнієві сполуки; соняшник; гречка; вика; педозем; дерново-літогенні грунти; сіро-зелені глини

\section{Вступ}

Дослідження агроекологічного зв’язку «грунт - рослина» важливе для вирішення проблеми відновлення деградованих грунтів і повернення їх у сільськогосподарське використання. Відкритий спосіб добування корисних копалин знищує великі площі сільськогосподарських угідь, які і без цього деградують у геометричній прогресії через інтенсивне ведення сільського господарства (Tsvetkova et al., 2016). Тому відновлення порушеного родючого шару - актуальна проблема сьогодення. Грунт важливий компонент біосфери, його відновлення після розробки відкритим способом марганцеворудних родовищ у Нікопольському марганцеворудному басейні - необхідна умова регенерації техногенного ландшафту. У більшості випадків роботи з рекультивації земель тривалі, а застосовувані технологічні прийоми екологічно малоефективні (Kul’bachko et al., 2015). Очевидно, що для підвищення ефективності рекультивації та розуміння процесів грунтогенезу в техногенних ландшафтах потрібні нові підходи.

Останнім часом інтерес до наземного циклу кремнію в системі «трунт - рослина» істотно зріс. Праці Wattean and Villemin (2001) i Matichenkov (2008) вказують на важливість дослідження його рухливих (активних) форм у системі «грунт - рослина». Зростання інтересу до кремнію пов'язане 3 його поліфункціональністю: він виступає як каркасний елемент крупнокристалічних мінералів, i, одночасно, як біогенний елемент (поряд 3 азотом, фосфором і калієм) контролює багато біологічних, хімічних та еволюційних процесів у наземних екосистемах біосфери.

Кремній - другий за розповсюдженістю елемент у земній корі. Основні дослідження ролі кремнію концентрувались на його участі у процесах вивітрювання, особливо у глинистих новоутвореннях, на буферних механізмах регулювання кислотності грунтів або хімічної денудації ландшафтів. Але лише декілька дослідників розглядали оксид кремнію як продукт грунтоутворення. Існує зацікавленість у поліпшенні знань мікробіологічних та ризосферних процесів, які сприяють мобілізації кремнієвих сполук, що поглинаються рослинами (Sommer et al., 2006). Механізми перерозподілу та роль біогенного кремнію у процесах десилікації грунтових профілів залишаються маловивченими (Lilian et al., 2016).

Кремній - біофільний елемент, що бере участь у біохімічних та фізіологічних процесах, сприяє підвищенню врожаю та якості рослинної продукції. У грунтах велика частина кремнію перебуває у формі малорозчинних сполук, недоступних рослинам. Вміст рухомих форм кремнію у грунтах досить низький: не перевищує 150-200 мг $\mathrm{SiO}_{2} /$ /к грунту (Matichenkov, 2014). Найважливішу роль у біогеохімічному кругообігу кремнію відіграють рослини, до яких він надходить і накопичується у вигляді фітолітів. Кремній у рослинах міститься в кількості, яку можна порівняти з умістом основних мікроелементів: у перерахунку на суху масу рослини містять $1-2 \% \mathrm{Si}$, а їх зола - 20-91\% (Bocharnikova et al., 2016).

Кремній необхідний рослинам для стійкості до вилягання, для вологонакопичення, заміщення іонів фосфору за його дефіциту тощо. У гумусовому горизонті кремнію, доступного для рослин, мало - 1,3-3,2\% його загального вмісту (Voronkov, 1969). Високий вміст органічної речовини у грунті знижує концентрацію доступного кремнію. Елемент помітно впливає на хімію та фізику грунтів: підвищує рухливість фосфору, кальцію, рівень $\mathrm{pH}$, ємність катіонного обміну та знижує вилуговування катіонів, поліпшує постачання кисню у грунт; кремнієва кислота бере участь в утворенні гумінових кислот (Voronkov, 1974).
Цикли вуглецю та кремнію тісно пов’язані з вивітрюванням силікатів. В обох циклах наземні рослини вносять значний внесок у процеси вивітрювання та грунтоутворення.

Гістохімічні дослідження рису показали, що корені накопичують Si та розподіляють його рівномірно (Abe and Wakatsuki, 2011; Choi et al., 2016; Horgan et al., 2016), хоча вважалось, що він міститься переважно в епідермальних тканинах. У транспіраційних органах (листках) кремній концентрується в епідермальних тканинах, утворює подвійний кутикулярний кремнієвий шар, який захищає рослини від надмірної транспірації та грибкових патогенів.

Агроекологічний аспект застосування аморфного кремнію в захисті рослин - зниження пестицидного навантаження в агроценозах, обмеження надходження ксенобіотиків і підвищення стійкості рослин до мутацій (Matichenkov, 2014), що пояснює міцніший зв'язок $\mathrm{Si}-\mathrm{O}-\mathrm{C}$, ніж $\mathrm{P}-\mathrm{O}-\mathrm{C}$ у ДНК і $\mathrm{PHK}$ рослини. Кремній проявляє себе як біологічний інсектицид проти Chilo partellus (Swinhoe, 1885) и Busseola fusca (Fuller, 1901), що забезпечує захист під час вирощування кукурудзи (Calatayud et al., 2016) - основного продукту харчування у Західній Африці.

Рослини, які інтенсивно асимілюють Si з грунту, називають кремнієфілами. Вміст Si в їх листі становить близько $2 \%$, за середніх показників - 0,25\%. Із культурних рослин виділяють таких кремнієфілів як злаки (рис, пшениця, ячмінь, овес, просо, кукурудза). Двоокис кремнію становить понад половину мінеральних речовин, які зернові засвоюють із грунту. Вміст $\mathrm{Si}$ у рослинах досягає максимуму до кінця вегетації.

Рис відомий як кремнієфіл, який містить Si на рівні $10 \%$ від маси сухої речовини (Ма and Yamaji, 2006). Кремній допомагає поліпшити толерантність до біотичних і абіотичних стресів (Savant et al., 1997; Ma, 2004). Si вже давно визнаний як один із ключових поживних речовин для поліпшення та стабілізації врожайності культур у Японії (Savant et al., 1997; Takahashi and Ma, 2002).

Під час дослідження рисової соломи в низинних і нагірних районах Західної Африки встановлено, що нагірний рис містить меншу кількість Si (Tsujimoto et al., 2014), ніж низинний. Ці дані свідчать про існування різних механізмів постачання $\mathrm{Si}$ між рівнинними та нагірними районами (Abe et al., 2016). Це пояснюється тим, що силікати зв'язуються за рахунок розчинених сполук заліза й алюмінію, утворюючи залізосилікати та алюмосилікати, що важко доступні для рослин рису, а в нагірних районах спостерігається вищий вміст $\mathrm{Fe} / \mathrm{Al}$ гідроксидів, ніж у рівнинних грунтах (Abe et al., 2010). Вміст активних форм кремнію у грунтах повинен перевищувати 50 мг/кг (Ma et al., 2006), але більшість сільськогосподарських угідь відчуває дефіцит цих сполук (Matichenkov, 2008), що пов'язано 3 неналежним ставленням до значення цього біофільного елемента у грунтах, його винесенням з урожаеєм.

Попередні дослідження (Ma and Takahashi, 1989; Alexandre et al., 1997; Sistani et al., 1997; Keller et al., 2012) показали, що застосування рисової соломи та органічних добрив може поповнити недостатність $\mathrm{Si}$ під час вирощування рису, що вказує на роль органічної речовини грунту як важливого джерела $\mathrm{Si}$ для рису. $\mathrm{pH}$ грунту впливає на грунтову доступність кремнію: найнижчий вміст Si у кислих грунтах (Tsujimoto et al., 2014).

Участь у направленому каталітичному синтезі органічних речовин як каталізатора - одна 3 важливих властивостей полікремнієвих кислот (Banerjee et al., 2006). Крім адсорбції органічних молекул, силікагель проводить своєрідне сортування органічної речовини, тому що має здатність селективної адсорбції тих органічних речовин, за присутності яких він утворився. Силікагель - не тільки адсорбент, а і каталізатор реакції конденсації ацетальдегіду, яка за кімнатної температури та 
нормального тиску за відсутності силікагелю не відбувається. Реакція конденсації ацетальдегіду йде 3 утворенням зв'язку $\mathrm{C}=\mathrm{C}$ (Bocharnikova and Matichenkov, 2001; Matichenkov, 2008; Matichenkov, 2014).

Кремнієва кислота добре взаємодіє з органічними та неорганічними сполуками, утворює розчинні комплекси (Dietzel, 2000). Іноді до розчинних кремнієвих сполук відносять колоїдні частинки та гелі кремнієвої кислоти (Banerjee, 2006). У наших дослідженнях теж установлено певну залежність між мінімальними та максимальними вмістами гумусу та загального кремнію. Коефіцієнт кореляції становить 0,84 (Chorna and Wagner, 2015a). Встановлено певну залежність між рухомими сполуками кремнію та органічною речовиною (Chorna and Wagner, 2015b), що потребує подальшого вивчення.

Велика частина досліджень кремнію у грунті та в системі «грунт - рослина» присвячена вивченню різних грунтових мінералів та біолітів, що логічно, оскільки основна маса сполук кремнію у грунті представлена діоксидом кремнію та різними алюмосилікатами (Orlov et al., 1975), а в рослинах присутні фітоліти, що складаються 3 аморфного діоксиду кремнію (Takahashi and Ma, 2002). Кварц як кристалічний різновид кремнезему характеризується високою стійкістю до вивітрювання та разом 3 іншими крупнокристалічними силікатами (польовим шпатом, плагіоклазом, піроксенами) та вторинними або глинистими кремнієвмісними мінералами (каолінітом, вермикулітом, смектитом тощо) формує скелет грунту (Orlov et al., 1975). Крім твердих сполук у грунтовому розчині постійно присутні розчинні форми $\mathrm{Si}$ - моно- та полікремнієві кислоти, кремнійорганічні сполуки, які мають високу хімічну та біологічну активність (Voronkov, 1975; Banerjee, 2006).

Кремній - невід'ємний компонент рослин. Його вміст у золі коливається від 0,16\% до 8,40\% і вище (Epstein, 1999). Найбільша кількість Si міститься у злаках, зольність яких досягає 8-16\% (Matichenkov, 2008). У більш продуктивних та стійких сортів злаків вміст кремнію вищий (Deren et al., 1992). Si поглинається рослинами у формі монокремнієвої кислоти та іï аніонів (Epstein, 1999; Takahashi and Ma, 2002). Транспорт кремнію по рослинних тканинах здійснюється, імовірно, за допомогою спеціалізованих транспортних білків (Ma et al., 2006).

Кремній (Si) корисний для рослин, його поглинання через транспортерів викликає захисну дію щодо біотичних i абіотичних стресів. У вищих рослин ідентифіковано дві групи кореневих транспортерів для Si: транспортерів надходження (Lsi1) та транспортерів відтоку (Lsi2). Обидва гени однаково виражені в коренях і пагонах, але цікаво, що вони показали набагато вищу експресію у пагонах, ніж у коренях хвоща, на відміну від Lsi2, який знайшли в інших рослинах. Хвощ - один із найбільших кремнійнакопичувачів серед рослин (Vivancos et al., 2016).

Найважливіший фактор, що впливає на вміст рухомого кремнію у грунті - його адсорбційні властивості. Адсорбція кремнієвої кислоти краще відбувається на різних модифікаціях кремнезему: гелях кремнієвої кислоти та мінералах типу опалу та кварцу (Takahashi and Ma, 2002; Bourrie, 2006). Крім того, адсорбція може відбуватися на гумінових кислотах. Доведено, що адсорбція кремнієвої кислоти посилюється зі збільшенням pH від 4 до 9 і зменшується за подальшого підвищення $\mathrm{pH}$.

Рослини поглинають кремній із грунтового розчину, глин i важкорозчинних силікатів. Джерелом цього елемента якоюсь мірою може бути кварц. Кремній - найдоступніший елемент для живлення рослин, що міститься у грунтовому розчині, де його вміст коливається в межах 1-200 мг/дм³ (Carlisle et al., 1997) й у середньому становить 30-40 мг/дм³. Рослинам рису доступні для споживання сполуки кремнію, що екстрагуються з грунту ацетатним буферним розчином. У багатьох випадках цієї кількості елемента мало для формування високого врожаю (Voronkov, 1974).

Залучення грунтів у сільськогосподарське виробництво порушує сформований у них баланс поживних елементів, оскільки значна їх частина щорічно виноситься з урожаєм. Зазвичай рослини виносять кремнію більше, ніж інших елементів. Для картоплі ця величина коливається від 50 до 70 кг/га, для зернових - від 100 до 300 кг/га. Максимальна кількість кремнію виноситься цукровою тростиною - до 700 кг/га за рік. За розрахунками В.В. Матиченкова, Е.А. Бочарникової та інших (Воcharnikova and Matichenkov, 2001; Matichenkov, 2008; Bocharnikova et al., 2016), щорічно у світі 210-224 млн т кремнію безповоротно відчужується з урожаєм. Тому у грунті сільськогосподарського призначення швидко знижується концентрація монокремнієвої кислоти, особливо в орному його горизонті.

Наростаючий дефіцит кремнію викликає низку негативних наслідків, оскільки кремній не тільки поживний, а і конструктивний грунтовий елемент. Дефіцит монокремнієвої кислоти та зменшення вмісту аморфного кремнезему викликає руйнування органомінерального комплексу грунту, прискорення деградації органічної речовини, погіршення мінералогічного складу. Для підтримання балансу монокремнієвої кислоти 3 метою забезпечення достатнього рівня для живлення рослин кремні$\epsilon м$ і запобігання деградації грунтів необхідне внесення кремнієвих добрив (Matichenkov, 2008). Кремній, поглинаючись рослинами в кількостях, що перевищують деякі макроелементи (фосфор, калій, а часто й азот) (Voronkov et al., 1978; Epstein, 1999; Matichenkov, 2008), безсумнівно, відіграє важливу безпосередню роль у фізіологічних процесах. Однак донині ці процеси вивчені слабко. Вкрай мало інформації про розчинні форми кремнію у тканинах рослин. Проте наявні дані вказують на можливість безпосередньої участі Si в метаболізмі рослин.

Тому практичний інтерес являє наукове обгрунтування високоефективних прийомів використання аморфного кремнію для підвищення врожайності сільськогосподарських культур і їх якісних характеристик на техногенно порушених грунтах, де головною метою виступає відновлення родючого шару грунту та повернення цих територій у сільськогосподарське використання. Отже, мета цього дослідження - встановити роль кремнієвих сполук в агроекологічному зв'язку «грунт - рослина» під час вирощування гречки (Fagopyrum esculentum Moench, 1794), вики (Vicia sativa Linnaeus, 1753) і соняшнику (Helianthus annuus Linnaeus, 1753) на насипному шарі чорнозему південного на лесоподібному суглинку та дерново-літогенних грунтах на лесоподібному суглинку та сіро-зелених глинах.

\section{Матеріал і методи досліджень}

Зразки грунту відбирали на ділянках Науково-дослідного стаціонару з рекультивації земель Дніпровського державного аграрно-економічного університету (м. Орджонікідзе, Дніпропетровська обл.) згідно з ДСТУ 4287:2004. Для встановлення оптимальної концентрації амфотерного кремнію ми заклали вегетаційний експеримент i провели серії лабораторних дослідів із додаванням метасилікату натрію 3 діапазоном концентрацій $0 \%, 0,1 \%, 0,2 \%, 0,3 \%$ і 0,4\% у перерахунку на $\mathrm{SiO}_{2}$ в лабораторії екології грунтів кафедри екології та охорони навколишнього середовища та у науково-дослідній лабораторії гідроекології Дніпровського державного аграрно-економічного університету.

Ми обрали за критерій оцінювання середню біомасу однієї рослини. Використали касети-розсадники з розміром комірки $40 \times 40 \times 60$ мм й усереднену пробу грунту (з кожної дослідної ділянки суміш із 40 зразків), масою 30 г, оптимальної для даного розміру комірки. $\mathrm{pH}$ визначали іономіром 150 - I (ДСТУ 8346:2015) у водній грунтовій витяжці, через 2 хв.

Доступний фосфор визначали за ISO 11263:1994 «Soil quality. Determination of phosphorus. Spectrometric determination of phosphorus soluble in sodium hydrogen carbonate solution». Ірунт, попередньо оброблений за ISO 11464, обробляли 0,5 моль/л розчином гідрокарбонату (pH 8,50) для відновлення концентрації іонів кальцію, алюмінію та заліза (III) за рахунок осадження карбонатів кальцію та алюмінію, а також гідроокисів заліза (III) та для вивільнення фосфорнокислих іонів у розчині. Прозору витяжку аналізували для визначення вмісту фос- 
фору спектрометричним методом, що включає утворення комплексу молібдатфосфату сурми (за кімнатної температури) чи фосфорно-молібденового комплексу (за високої температури), доведених під час додавання аскорбінової кислоти в обох випадках до утворення глибоко пофарбованого синього комплексу.

Азот нітратний (ДСТУ 7629:2014) визначали на спектрофотометрі КФК 3 за довжини хвилі 440 нм у водній витяжці 3 реакцією дисульфофенолової кислоти з нітратами, в результаті якої виникав тринітрофенол, який у лужному середовищі давав солі, що забарвлювали розчин у жовтий колір. Інтенсивність забарвлення пропорційна концентрації нітратного азоту.

Азот амонійний (ДСТУ 7629:2014) визначали на фотоколориметрі Unico за довжини хвилі 440 нм. Метод заснований на тому, що катіони амонію екстрагували з грунту за допомогою $2 \% \mathrm{KCl}$ (співвідношення грунту до розчину $-1: 10$ ). У взаємодіï $\mathrm{NH}_{4} \mathrm{Cl}$ із реактивом Неслера (лужним розчином $\mathrm{K}_{2} \mathrm{HgJ}_{4}$ ) розчин забарвлюється, оскільки утворюється йодистий меркурамоній жовтого кольору.

Варіанти експерименту закладали у восьмикратній повторності. Експеримент тривав 14 діб, полив проводили кожні три доби. Температуру та вологість повітря підтримували у діапазоні $+21 \ldots+23{ }^{\circ} \mathrm{C}$ та 50-70\% відповідно. Представником незлакових зернових культур обрано гречку, зернобобових - вику, олійних - соняшник. Дані аналізували за допомогою програми Statistica 10.0 (StatSoft Inc., USA, 2011), розраховували стандартні відхилення (SD), середнє, максимальне та мінімальне значення. Проаналізовано 240 зразків за діаграмами розмаху.

\section{Результати та їх обговорення}

У попередніх публікаціях ми встановили, що вміст загального кремнію варює від $52 \%$ до $32 \%$ зі зниженням за глибиною (Chorna and Wagner, 2015c), а концентрація рухомого кремнію коливається від 6,4 до 19,4 мг/100 г, що свідчить про дефіцит цього елемента. Також установили вміст доступного фосфору та азоту для розуміння кількості основних мікроелементів (табл.). $\mathrm{pH}$ досліджуваних грунтів коливається від 7,1 до 7,8 , що характеризує грунти як слабколужні. Вміст доступного азоту на кожному типі досліджуваних грунтів низький.

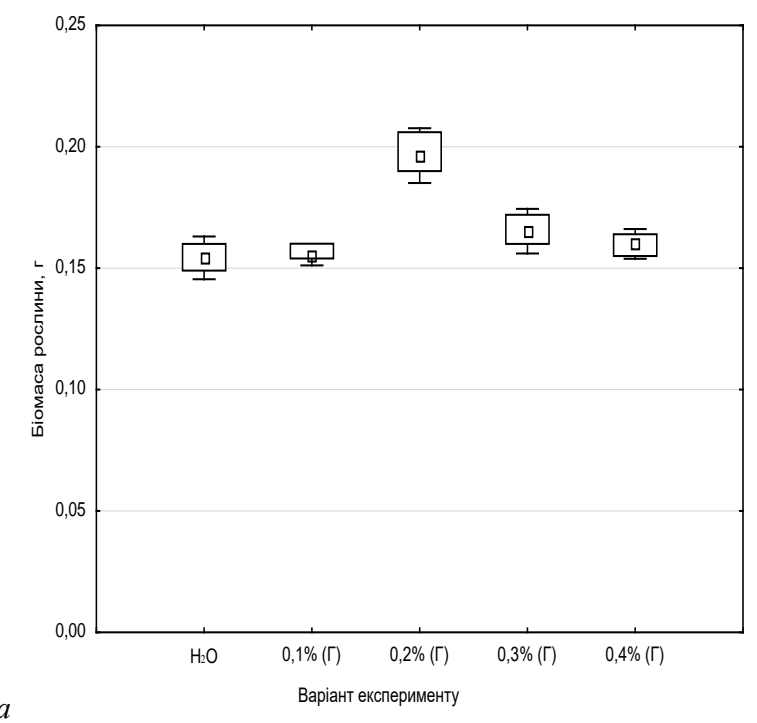

Рис. 1. Зміна біомаси гречки на техногенно порушених грунтах із додаванням аморфного кремнію:

0,1\%, 0,2\%, 0,3\% та $0,4 \%$ розчини $\mathrm{SiO}_{2} ; a$ - насипний шар чорнозему південного на лесоподібному суглинку; $\sigma$ - дерново-літогенні грунти на лесоподібному суглинку

Вирощуючи гречку на насипному шарі чорнозему південного на лесоподібних суглинках, отримали рослини із середньою біомасою $0,154 \pm 0,0045$ г у варіанті $3 \mathrm{H}_{2} \mathrm{O}$, а на дерноволітогенних грунтах на лесоподібному суглинку $-0,086 \pm 0,0114$ г, що практично удвічі менше. Накопичення біомаси рослинами
Таблиця

Вміст рухомих сполук фосфору та азоту

у техногенно порушених грунтах $(\mathrm{x} \pm \mathrm{SD})$

\begin{tabular}{lcc}
\hline \multicolumn{1}{c}{ Тип грунту } & $\begin{array}{c}\text { Вміст азоту, } \\
\text { мг } / 100 \text { г }\end{array}$ & $\begin{array}{c}\text { Bміст фосфору, } \\
\text { мг } / 100 \text { г }\end{array}$ \\
\hline $\begin{array}{l}\text { Педоземи (насипний шар } \\
\text { чорнозему південного на }\end{array}$ & $0,30 \pm 0,012$ & $2,71 \pm 0,068$ \\
$\begin{array}{l}\text { лесоподібному суглинку) } \\
\text { Дерново-літогенні грунти }\end{array}$ & $0,72 \pm 0,025$ & $1,20 \pm 0,018$ \\
$\begin{array}{l}\text { на лесоподібному суглинку } \\
\text { Дерново-літогенні грунти }\end{array}$ & $0,65 \pm 0,023$ & $1,22 \pm 0,041$ \\
\hline на сіро-зелених глинах & \\
\hline
\end{tabular}

Вміст рухомого фосфору за градаціями Кірсанова та Чирикова характеризується як низький, тобто грунти погано забезпечені доступними сполуками, а за класифікацією Олсена (ISO 11263:1994) педоземи належать до середньозабезпечених, а дерново-літогенні грунти - до низькозабезпечених. Вміст фосфору у педоземах удвічі більший, ніж в інших досліджуваних грунтах, а вміст азоту, навпаки, вдвічі менший. Дерново-літогенні грунти на лесоподібному суглинку та дерново-літогенні грунти на сіро-зелених глинах мають приблизно однакові концентрації доступного азоту та фосфору.

Гречка звичайна - однорічна рослина зі стрижневою слабко розвиненою кореневою системою. Біомаса коріння розвивається у шарі 0-40 см і добре засвоює важкорозчинні сполуки фосфору та калію. Швидкість поглинання поживних речовин iз важкодоступних сполук грунту у грчки вища за багато інших сільськогосподарських культур.

Найбільша біомаса гречки на педоземі, дерново-літогенних грунтах і лесоподібних суглинках отримана за додавання $0,2 \%$ розчину $\mathrm{SiO}_{2}$ (рис. 1,2 ). Додавання $0,1 \%$ розчину $\mathrm{SiO}_{2}$ ефекту на обох типах техногенно порушених грунтів не дало. Така сама тенденція встановлена й у публікаціях Dovgun and Janishevskaja (2007). У варіантах із $0,3 \%$ та $0,4 \%$ розчинами $\mathrm{SiO}_{2}$ встановлено незначний приріст біомаси гречки, але значно менший, ніж за $0,2 \%$ розчину, тому їх використання недоцільне. У працях Matichenkov (2008) теж застосовано $0,2 \%$ розчин амфотерного кремнію, який, навіть за розведення у 20 разів, викликав збільшення біомаси на 7-16\%.

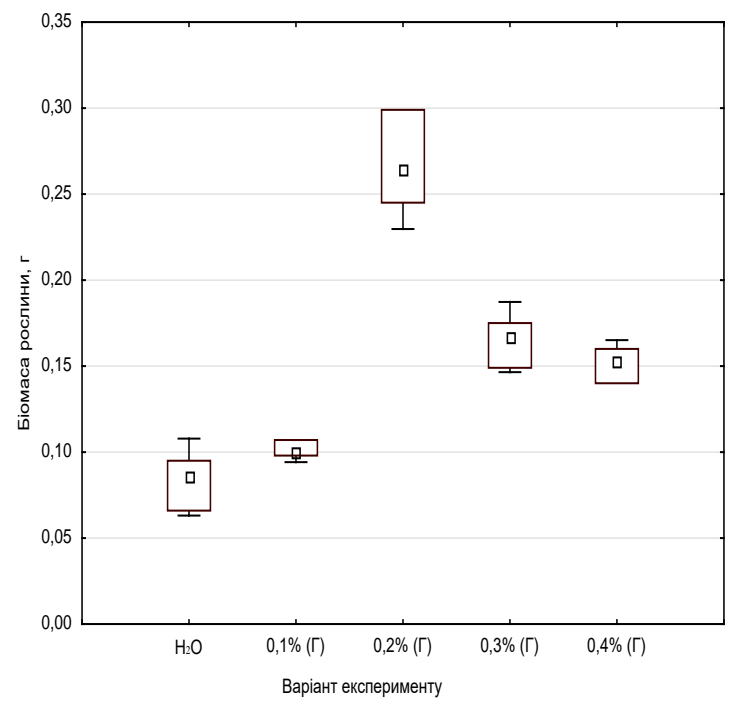


виснаження запасів фітолітів. Існує багато видів і форм фітолітів, що може синтезувати навіть одна рослина. Зміна кремнієвого живлення рослин впливає на форми фітолітів. Наведено докази того, що видалення соломи може спричинити виснаження грунтів за 10 років через винесення запасів кремнію, який міститься у фітолітній формі. Для підтримання оптимального рівня $\mathrm{Si}$ внесення інших грунтових силікатів (таких як глинисті мінерали) у грунти може стати ключовим параметром, коли солома йде на експорт (Keller et al., 2012). Особливо велике значення кремній має для зернових культур, тому його внесення сприяс підвищенню врожаїв пшениці та кукурудзи. У фосфогіпсі, за різними даними, кремнію міститься близько $1 \%$, тому його внесення за норми 1 т/га істотно поліпшує живлення рослин (Calatayud et al., 2016).

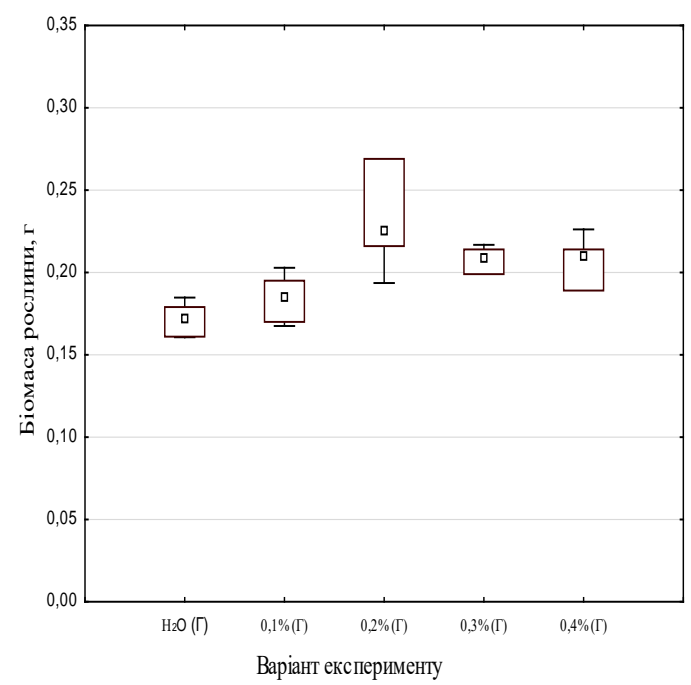

Рис. 2. Зміна біомаси гречки на дерново-літогенних грунтах на сіро-зелених глинах із додаванням аморфного кремнію: $0,1 \%, 0,2 \%, 0,3 \%$ та $0,4 \%$ розчини $\mathrm{SiO}_{2}$

Використовуючи $0,2 \%$ розчин $\mathrm{SiO}_{2}$ на перших стадіях вирощування гречки на дерново-літогенних грунтах на сірозелених глинах, отримали найкращі результати, як і на інших типах досліджуваних грунтів. Під час вирощування гречки у контрольних зразках на трьох типах грунтів, на дерново-

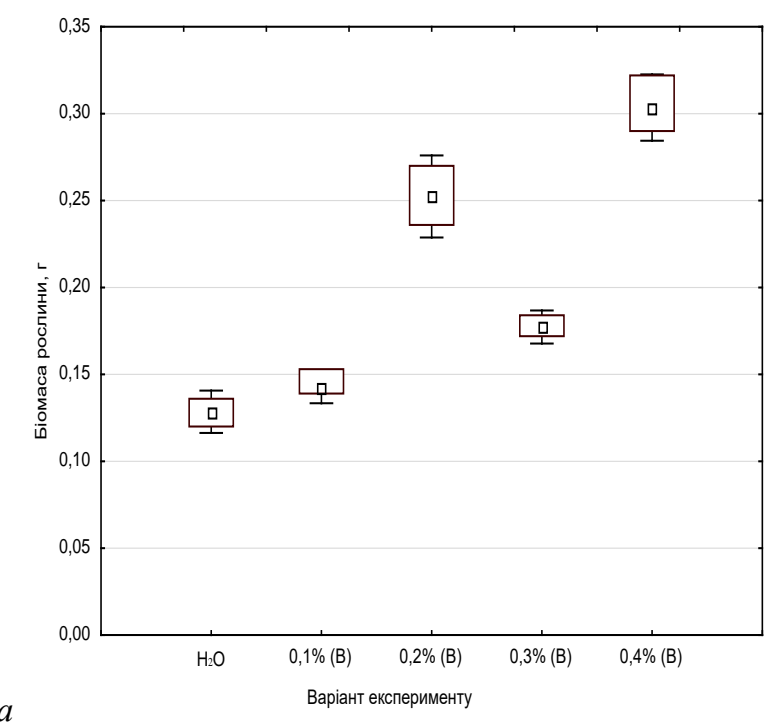

a

Рис. 3. Зміна біомаси вики на техногенно порушених грунтах із додаванням аморфного кремнію: $a$ - насипний шар чорнозему південного на лесоподібному суглинку, $\sigma$ - дерново-літогенні грунти на лесоподібному суглинку; 0,1\%, 0,2\%, 0,3\% та 0,4\% розчини $\mathrm{SiO}_{2}$

Вика - однорічна бобова культура, яку використовують у суміші з вівсом та іншими рослинами, що підтримують їі стебла, які в’ються. Вика швидко нарощує біомасу, добре цінується за це, може висіватися навесні перед основними культурами. Ії викори- літогенних грунтах на сіро-зелених глинах зафіксовано найбільше значення біомаси $-0,170 \pm 0,0112$ г. Цікаво, що внесення $0,3 \%$ i $0,4 \%$ розчину $\mathrm{SiO}_{2}$ на дерново-літогенних грунтах на сіро-зелених глинах краще спрацювало та відбилось на збільшенні біомаси, ніж в інших досліджуваних грунтах.

Найчутливішими до внесення кремнієвих сполук виявилися дерново-літогенні грунти на лесоподібному суглинку, де середня маса рослини склала $0,2639 \pm 0,0174$ г. Мода, медіана та середнє значення не збігаються. Асиметрія значима на трьох типах техногенно порушених грунтів; вона правостороння, що свідчить про перевагу значень більших ніж середнє. Розраховані критерії асиметрії та ексцесу, менші ніж 3 в кожному експерименті, що дає можливість стверджувати про відсутність відмінностей між емпіричним і теоретичним нормальним розподілами (Siegel and Castellan, 1998).

Дані, отримані для гречки, свідчать, що вона добре відгукується на вміст фосфору у грунтах; чим його більше, тим показник біомаси у контролі вищий. А ось азот ефективний разом із кремнієм, у варіанті з дерново-літогенними грунтами на лесоподібному суглинку, де зафіксовано найбільше значення біомаси рослини, зареєстроване під час додавання $0,2 \%$ розчину $\mathrm{SiO}_{2}$ та доступного азоту; можливо, ці елементи у грунті - синергісти.

Зростання біомаси рослин пов'язане з акумулюванням кремнію у корінні та стеблах і використання його абсорбувальної здатності під час посухи (Kang et al., 2016), що зумовлює зростання активності процесів фотосинтезу та діяльності антиоксидантних ензимів. Але у праці Lavinsky et al. (2016) кремній визнано якісним елементом для підвищення врожайності рису за рахунок збільшення кількості зерна та маси 1000 зернин; але площа листя та біомаса рослин залишались незмінними.

Matichenkov (2008) установив, що оптимальна кількість аморфного кремнію на 2,0-2,5 тижня пришвидшує дозрівання кукурудзи, а насіння ячменю та рису під час проростання добре відгукуються збільшенням кореневої біомаси, підсилює фотосинтетичні та ростові процеси, прискорює його дозрівання. На засвоєння кремнію впливає NPK та обмінні процеси у грунті (Matichenkov, 2014). Він збільшує посухостійкість рослин (Dovgun and Janishevskaja, 2007), проявляє фунгіцидні властивості, зменшує ураженість рослин шкідливими комахами, підвищує стресостійкість під час зниження температури.

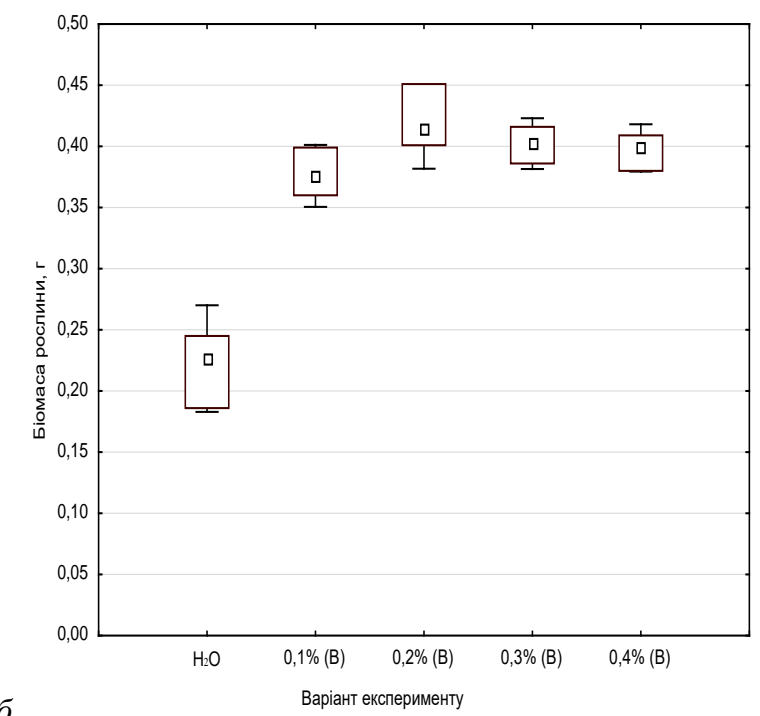


фосфатних і калійних добрив. Після розкладання у грунті біомаса вики стає легкозасвоюваним добривом. Рослина має дренувальні властивості, покращує структуру грунту, підвищує пухкість і вологоємність. Поліпшує умови життєдіяльності грунтових мікроорганізмів, червів і комах, під час розкладання служить їм кормом. Тому вона може виявитись перспективною культурою для біологічної рекультивації земель.

В усіх варіантах вирощування вики на дерново-літогенних грунтах на лесоподібних суглинках біомаса рослин у 1,32,6 раза більша, ніж у варіантах на педоземі. Додавання розчинів $0,2 \%$ та $0,4 \% \mathrm{SiO}_{2}$ у досліді на педоземах сприяло зростанню біомаси $(0,252 \pm 0,0120$ та 0,304 $\pm 0,0097$ г), а внесення кремнієвих сполук у всіх варіантах вирощування на дерноволітогенних грунтах на лесоподібних суглинках викликало збільшення біомаси вики удвічі відносно експерименту без додавання кремнієвих сполук.

У всіх варіантах експерименту додавання розчинів аморфного кремнію під час вирощування вики дало позитивні результати відносно контролю (рис. 3). Найбільшу біомасу зафіксовано у варіанті експерименту 3 додаванням $0,2 \%$ розчину $\mathrm{SiO}_{2}$, а подальше збільшення концентрації розчинів не дало позитивних результатів (рис. 4). Діаграма розподілу біомаси вики в експерименті на дерново-літогенних грунтах свідчить про те, що $0,2 \%$ розчин кремнію - найкращий. Збільшення концентрації розчинів кремнію до $0,3 \%$ і 0,4\% позитивного ефекту відношенню результатів із $0,2 \%$ розчином не викликало. Склалось враження, що $0,4 \%$ розчин пригнічував розвиток рослини, що, можливо, пов’язано з утворенням гелеподібної плівки. Тенденція важливості макроелементів у техногенно порушених грунтах залишається незмінною. На перших етапах формування вики важливими стають як доступний фосфор, так і азот, тому що у рослини тільки формується азотфіксувальна здатність і вона ще не в змозі забезпечити себе цим елементом.

У дослідженнях із використанням кремнійгельумісних сполук у вигляді добрив спостерігали збільшення концентрації Si у соломі ячменю на 5-15\%, пшениці - на 5-20\%, виковівсяної суміші - на 25-40\%. Сполуки мали тривалу дію та підвищували вміст у зерні пшениці та зеленій масі гороховівсяної суміші проламінів і глютелінів. Винесення кремнієвої кислоти 3 урожаєм ячменю склало 400-600 кг/га, пшениці - 100170 кг/га, виковівсяної суміші - 50-90 кг/га (Kolesnikov, 2001). Не визначено механізми участі кремнію в метаболізмі рослин (Dobrovol'skij and Nikitin, 2012). Однак уважають, що вони пов’язані зі зміною активності ферментів (можуть пригнічувати інвертазу та кислу фосфатазу в рослинах).

Відносно контролю вика збільшує як біомасу стебла, так і біомасу кореня. Savant et al. (1999) стверджує, що підживлення рослин кремнієвими сполуками сприяє збільшенню ваги коренів на $20-50 \%$, їх обсягу, загальної та робочої адсорбувальної поверхні (Takahashi and Ma, 2002), поліпшує кореневе дихання (Yamauchi and Winslow, 1995). Kuai et al. (2016) стверджують, що обробка розчином метасилікату натрію коренів на стадії проростка та ранньої стадії бутонізації ріпаку після застосування кремнію кількість насінин у стручку знизилась, але збільшилась кількість стручків на одній рослині, а також вага 1000 зерен, поліпшуючи тим самим загальний вихід продукції. Внесення кремнієвого добрива збільшило діаметр кореня та вміст лігніну, тим самим підвищуючи стійкість до вилягання, а також кількість $\mathrm{SiO}_{2}$ у самій рослині, але зменшило висоту рослин.

3 урахуванням врожайності та механічного збирання рослин результати цього дослідження показують, що оптимальний ефект розчину кремнієвих сполук на обох сортах ріпаку проявився під час ранньої стадії бутона з умістом монокремнієвої кислоти 0,96 мМ. Кремній для вики виявився дуже важливим елементом на початкових стадіях на техногенно порушених грунтах. Він пришвидшив iï розвиток і знизив стрес рослин за нестачі поживних речовин.

Тканини рослин, які мають найбільшу здатність до транспірації, характеризуються найбільшим вмістом кремнію (листя пшениці, сорго, жита тощо), проте також говориться, що від- мінності вмісту кремнію можна пояснити тільки різною кількістю води, що випаровується (Dovgun and Janishevskaja, 2007; Abe et al., 2016). Доступний кремній постійно перебуває в дефіциті (Sommer et al., 2006). Проблеми дефіциту Si можуть реєструватися частіше там, де швидкими темпами збільшується виробництво рису та ведеться інтенсивне виробництво (Abe and Wakatsuki, 2011). Дефіцит Si може зробити рослини рису чутливішими до стресу (Savant et al., 1997).



Рис. 4. Зміна біомаси біомаси вики на дерново-літогенних грунтах на сіро-зелених глинах із додаванням кремнієвих добрив: $0,1 \%, 0,2 \%, 0,3 \%$ та $0,4 \%$ розчини $\mathrm{SiO}_{2}$

Соняшник - головна олійна культура України, темпи виробництва якої зростають із року в рік. Порівняно $з$ іншими культурами він має високу рентабельність, що спонукало українських аграріїв збільшити посівні площі під цю культуру в 1,2 раза у 2016 році. Соняшник вимогливий до грунтів. Найкращими для нього визнані суглинкові та супіщані чорноземи. Це культура інтенсивного мінерального живлення. Пришвидшенню розвитку соняшнику та збільшенню врожайності сприяють мінеральні та органічні добрива. Вирощування соняшнику залежить від багатьох чинників: температурних показників, кількості опадів, типів грунтів та рівня мінерального живлення. Піщані, важкосуглинкові та глинисті грунти з високим вмістом вапна непридатні для цієї культури. Допустима рН грунту - 5,77,0, а рН досліджуваних грунтів - слабо лужний, що робить їх непридатними для вирощування соняшнику. За таких умов багато важливих мікроелементів стають недоступними. Наприклад бор і залізо, які відіграють важливу роль на всіх стадіях розвитку рослини.

Біомаса соняшнику на педоземах і дерново-літогенних грунтах на лесоподібному суглинку та сіро-зелених глинах склала $0,150 \pm 0,0114,0,114 \pm 0,0044$ та $0,332 \pm 0,021$ г, відповідно (рис. 5). Під час внесення кремнієвих сполук біомаса рослини збільшилась у 2-4 рази на дерново-літогенних грунтах на лесоподібному суглинку та учетверо - на педоземах відносно варіанта без унесення кремнієвих добрив. Придатнішими виявились педоземи на лесоподібному суглинку (в 1,25 1,32 раза відносно біомаси рослин).

Під час вирощування соняшнику у контрольному варіанті біомаса рослин на педоземі та дерново-літогенних грунтах на лесоподібному суглинку приблизно однакова, на дерново-літогенних грунтах на сіро-зелених глинах - удвічі більша. Найкращим варіантом експерименту із соняшником виявився $0,2 \%$ розчин кремнію на дерново-літогенних грунтах на сіро-зелених глинах - це також найкращий показник серед усіх культур. Не встановлено якісної залежності доступних форм азоту та фосфору. 

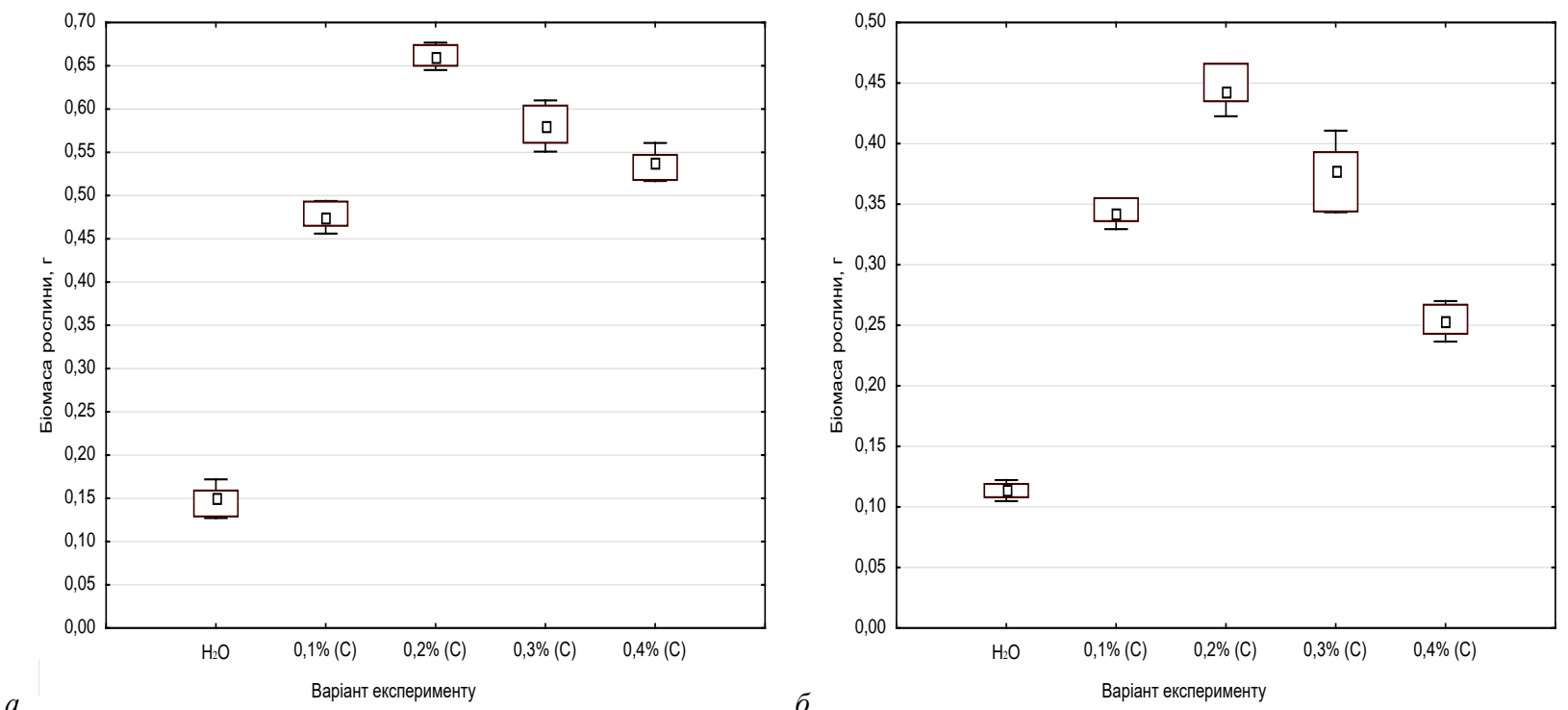

Рис. 5. Зміна біомаси соняшнику на техногенно порушених грунтах із додаванням кремнієвих добрив:

$a$ - насипний шар чорнозему південного на лесоподібному суглинку, $\sigma$ - дерново-літогенні грунти на лесоподібному суглинку; $0,1 \%, 0,2 \%, 0,3 \%$ та $0,4 \%$ розчини $\mathrm{SiO}_{2}$

Варіант експерименту з $0,2 \%$ розчином $\mathrm{SiO}_{2}$ виявився найефективнішим за умов вирощування соняшнику на всіх типах досліджуваних грунтів. Під час вирощування на техногенно порушених грунтах рослина відчуває нестачу елементів живлення та добре відгукується на внесення кремнієвих сполук. Низькі показники доступного азоту та фосфору добре характеризують отримані дані контролю. Внесення $0,2 \%$ розчину кремнію універсальне для будь-якого типу досліджуваних грунтів. У разі додавання амфотерного кремнію найкращі показники біомаси вики та гречки (рис. 6) зафіксовано на дерново-літогенних грунтах на лесоподібному суглинку, а соняшнику - на дерново-літогенних грунтах на сіро-зелених глинах. У контрольних зразках під час вирощування гречки найкращий результат отримано на дерново-літогенних грунтах на сіро-зелених глинах

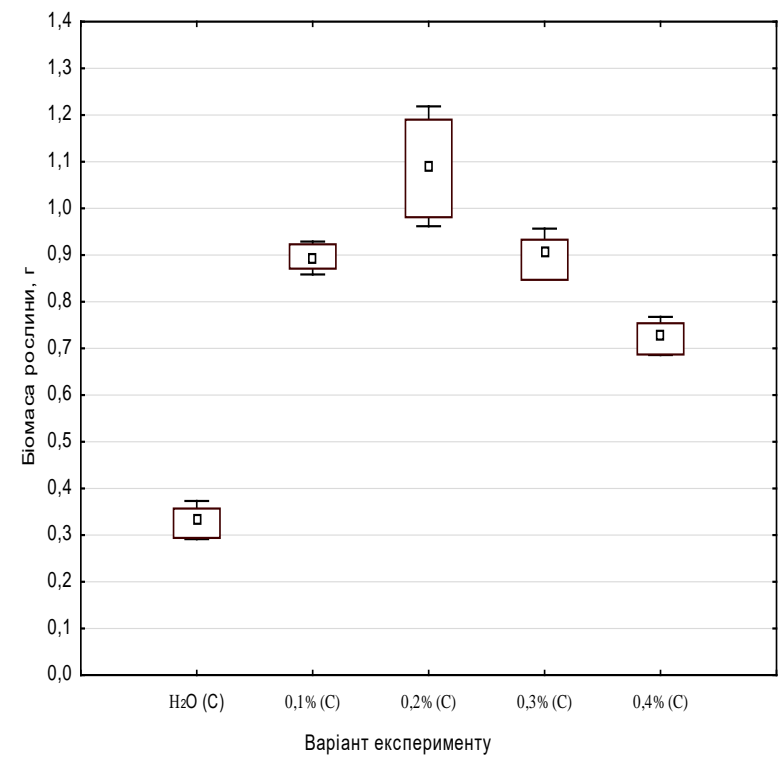

Рис. 6. Зміна біомаси гречки на дерново-літогенних грунтах на сіро-зелених глинах із додаванням кремнієвих добрив: $0,1 \%, 0,2 \%, 0,3 \%$ та $0,4 \%$ розчини $\mathrm{SiO}_{2}$

У нашому вегетаційному експерименті біомаса рослин збільшувалась від 1,27 до 3,50 раза відносно контролю. У працях Choi et al. (2016) обробка насіння рису $\mathrm{SiO}_{2}$ збільшила удвічі свіжу біомасу, а суху - в 1,7 раза відносно рослин, які попередньо не обробляли. Збільшився вміст білка в зерні 3
$6,0 \%$ до 7,2\%. Все це відбувалось у грунтах, що мали сольовий стрес. А вирощуючи ячмень, з'ясували, що вага стебла за оптимального кремнієвого живлення $\left(20\right.$ мг $\mathrm{SiO}_{2} /$ дм$\left.^{3}\right)$ через 30 діб збільшилася на 15-25\%.

Для підтвердження висновків провели ранговий дисперсійний аналіз за критерієм Краскела - Уоліса (непараметрична альтернатива одновимірному дисперсійному аналізу). Критерій Краскела Уоліса високо значимий $\mathrm{P}<0,001$. Таким чином, характеристики різних варіантів експерименту чисельно відрізняються. Найбільша середня сума рангів відповідає варіантам експериментів 3 0,2\% розчином $\mathrm{SiO}_{2}$, що визначає цей розчин найефективнішим.

\section{Висновки}

Внесення кремнієвих сполук відіграє важливу роль у системі «грунт - рослина» та позитивно впливає на біомасу сільськогосподарських культур. Соняшник і гречка проявили себе найкраще на дерново-літогенних грунтах на сіро-зелених глинах, а вика - на дерново-літогенних грунтах на лесоподібному суглинку. Варіанти експериментів з $0,2 \%$ розчином $\mathrm{SiO}_{2}$ виявились найефективнішими для вирощування будь-якої 3 обраних культур на всіх типах досліджуваних грунтів. У разі додавання $0,2 \%$ розчину $\mathrm{SiO}_{2}$ гречка та вика найкраще проявили себе на дерново-літогенних грунтах на лесоподібному суглинку, а соняшник - на дерново-літогенних грунтах на сірозелених глинах. Вміст рухомих сполук фосфору та азоту низький у всіх типах досліджуваних грунтів.

Подальші дослідження будуть направлені на вивчення взаємозв'язків кремнієвих сполук з іншими важливими мікроелементами (залізо, бор, манган, цинк) у системі «грунт - рослина», встановлення їх місця у живленні рослин, процесах грунтогенезу та ролі в утворенні родючого шару грунту.

\section{References}

Abe, M., Buri, M., Kiepe, P., Roland, N. I., Susumu, S., \& Wakatsuki, T. (2010). Possible influence of termites (Macrotermes bellicosus) on forms and composition of free sesquioxides in tropical soils. Pedobiologia, 53(5), 301-306.

Abe, S. S., \& Wakatsuki, T. (2011). Sawah ecotechnology: A trigger for a rice green revolution in sub-Saharan Africa: Basic concept and policy implications. Outlook on Agriculture, 40, 221-227.

Abe, S. S., Wakatsuki, T., \& Yamasaki, B. Y. (2016). Assessing silicon availability in soils of rice-growing lowlands and Neighboring uplands in Benin and Nigeria. Rice Science, 23(4), 196-202. 
Alexandre, A., Colin, F., Koud, J.-M., \& Meunier, J.-D. (1997). Plant impact on the biogeochemical cycle of silicon and related weathering processes. Geochimica et Cosmochimica Acta, 61(3), 677-682.

Banerjee, S. K., Guyodo, Y., LaPara, T. M., Anschutz, A. J., Penn, R. L., Geiss, C. E., \& Zanner, W. (2006). Rock magnetic, chemical and bacterial community analysis of a modern soil from Nebraska. Earth and Planetary Science Letters, 251, 168-178.

Bocharnikova, E. A., \& Matichenkov, V. V. (2001). The relationship between silicon and soil physical and chemical properties. Studies in Plant Science, 8, 209-219.

Bocharnikova, E., Jiang, J., Matichenkov, A., Saihua, L., Xionghui, J., \& Yunhe, X. (2016). Prospective for remediation and purification of wastes from Xikuangshan mine by using Si-based substances. Journal of Environmental Management, 172, 77-81.

Calatayud, A., Gatebe, E., Gathara, M., Johansson, T., Juma, G., Kibe, A., Musyoka, B., Mwalusepo, S., Njuguna, E., Okuku, G., Ong’amo, G., Subramanian, S., \& Williamson, D. (2016). Can climate-driven change influence silicon assimilation by cereals and hence the distribution of lepidopteran stem borers in East Africa? Agriculture, Ecosystems and Environment, 224, 95-103.

Cantais, F., Fraysse, F., Meunier, J. D., Pokrovsky, O. S., \& Schott, J. (2006). Aqueous reactivity of phytoliths and plant litter: Physicochemical constraints on terrestrial biogeochemical cycle of silicon. Journal of Geochemical Exploration, 88, 202-205.

Choi, E.-S., Sukweenadhi, J., Kim, Y.-J., Jung, K. H., Koh, S-C., Hoang, A., \& Yang, D.-C. (2016). The effects of rice seed dressing with Paenibacillus yonginensis and silicon on crop development on South Korea's reclaimed tidal land. Field Crops Research, 188, 121-132.

Choma, V., \& Wagner, I. (2015a). Doslidzhennja vmistu zagal'nogo kremniju u chornozemi zvichajnomu ta tehnozemi [Analysis of general silicon's content in the blacksoil usual and technosoil]. Science World, 38(24), 30-35.

Chorna, V., \& Wagner, I. (2015b). Uchast' kremniєvih spoluk ta guminovih kislot u formuvanni vlastivostej rruntu [Participation of compouds' silicon and humic acidsin the formation of soil characteristics] Collected words of Dnipropetrovsk State Agrarian and Economic University. Natural agricultural firm in Ukraine: Issues of establishment, future developments, 1, 151-153 (in Ukrainian).

Chorna, V., \& Wagner, I. (2015c). Osoblivosti rozpodilu vmistu zagal'nogo kremniju u chornozemi zvichajnomu [Distribution feature of general silicon content in normal blacksoil]. Science Without Borders. Biological Sciences, 19, 75-77 (in Ukrainian).

Deren, C. W., Datnoff, L. E., \& Snyder, G. H. (1997). Silicon fertilization for disease management of rice in Florida. Crop Protection, 16(6), 525-531.

Dietzel, M. (2000). Dissolution of silicates and the stability of polysilicic acid. Geochimica et Cosmochimica Acta, 64(19), 3275-3281.

Dobrovol'skij, G. (ed.) (2012). Jekologija pochv: Uchenie ob jekologicheskih funkcijah pochv [Ecology of soils: Doktrine of ecological function of soils]. Moscow University Press, Moscow (in Russian).

Dovgun, B., \& Janishevskaja, O. L. (2007). Urozhaj i kachestvo l'na-dolgunca pri primenenii kremnijsoderzhashhih udobrenij i kobal'ta [Productivity and quality of bast fiber on application of silicon and cobalt]. Plodorodie, 2, 2728 (in Russian).

Epstein, E. (1999). Silicon. Annual Review of Plant Physiology and Plant Molecular Biology, 50, 641-664.

Hirose, S., Kawahigashi, H., Hayashi, E., Ohkawa, H., \& Ohkawa, Y. (2002) Pesticide biochemistry and physiology phytotoxicity and metabolism of ethofumesate in transgenic rice plants expressing the human CYP2B6 gene. Pesticide Biochemistry and Physiology, 74(3), 139-147.

Horgan, F. G., Palenzuela, A. N., Stuart, A. M., Naredo, A. I., Ramal, A. F. Bernal, C. C., \& Almazan, M.-L. (2016). Effects of silicon soil amendments and nitrogen fertilizer on apple snail (Ampullariidae) damage to rice seedlings. Crop Protection, 91, 123-131.

Kang, J., Zhao, W., \& Zhu, X. (2016). Silicon improves photosynthesis and strengthens enzyme activities in the C3 succulent xerophyte Zygophyllum xanthoxylum under drought stress. Journal of Plant Physiology, 199, 76-86.

Keller, C., Guntzer, F., Barboni, D., Labreuche, J., \& Meunier, J-D. (2012). Impact of agriculture on the Si biogeochemical cycle: Input from phytolith studies. Comptes Rendus Geoscience, 344, 739-746.

Keller, C., Meunier, J.-D., Miche, H., \& Rizwan, M. (2012). Effect of silicon on reducing cadmium toxicity in durum wheat (Triticum turgidum L. c Claudio W.) grown in a soil with aged contamination. Journal of Hazardous Materials, 209-210, 326-334.
Kolesnikov, M. (2001). Formy kremnija v rastenijah [Silicon's form in the plants]. Advances in the Biology and Chemistry, 41, 301-333 (in Russian).

Kuai, J., Sun, Y., Guo, C., Zhao, L., Zuo, Q., Wu, J., \& Zhou, G. (2017). Root-applied silicon in the early bud stage increases the rapeseed yield and optimizes the mechanical harvesting characteristics. Field Crops Research, 200, 88-97.

Kul'bachko, Y. L., Didur, O. O., Loza, I. M., Pakhomov, O. E., \& Bezrodnova, O. V. (2015). Environmental aspects of the effect of earthworm (Lumbricidae, Oligochaeta) tropho-metabolic activity on the $\mathrm{pH}$ buffering capacity of remediated soil (steppe zone, Ukraine). Biology Bulletin, 42, 899-904.

Lavinsky, A. O., Detmann, K. C., Reis, J., Avila, R. T., Sanglard, M. L., Pereira, L. F., Sanglard, L., Rodrigues, F. A., Araujo, W. L., \& DaMatta, F. M. (2016). Silicon improves rice grain yield and photosynthesis specifically when supplied during the reproductive growth stage. Journal of Plant Physiology, 206, 125-132.

Ma, J. F. (2004). Role of silicon in enhancing the resistance of plants to biotic and abiotic stresses. Soil Science and Plant Nutrient, 11-18.

Ma, J. F., \& Takahashi, E. (1989). Release of silicon from rice straw under flooded conditions. Soil Science and Plant Nutrient, 35, 663-667.

Ma, J. F., \& Takahashi, E. (2002). Silicon sources for agriculture. Soil, Fertilizer, and Plant Silicon Research in Japan, 5-26.

Ma, J. F., \& Yamaji, N. (2006). Silicon uptake and accumulation in higher plants. Trends in Plant Science, 11(8), 392-397.

Ma, J. F., Tamai, K., Yamaji, N., Mitani, M., Konishi, S., Katsuhara, M., Ishiguro, M., Murata, Y., \& Yano, M., (2006). Silicon transporter in rice. Nature, 440, 688-691.

Matichenkov, I. (2014). Izuchenie vzaimovlijanija kremnievyh, fosfornyh, azotnyh udobrenij v sisteme "pochva - rastenie" [Study of synergy of silicic, phosphoric, nitrogenic fertilizers in the system of "soil - plant"]. Moscow University Press, Moscow (in Russian).

Matichenkov, V. V. (2008). Rol' podvizhnyh soedinenij kremnija v rastenijah sisteme "pochva - rastenie" [Role of mobile silicon's compouds in plants and the "soil - plant" system]. Institute of Fundamental Problems of Biology of the RAS, Pushhino.

Orlov, D. S., Ammosova, Y. M., \& Glebova, G. I. (1975). Molecular parameters of humic acids. Geoderma, 13(3), 211-229.

Sanglard, L. M., Detmann, K. C., Martins, S. C., Teixeira, R. A., Pereira, L. F., Sanglard, M. L., Fernie, A. R., Araujo, W. L., \& Fabio, M. (2016). The role of silicon in metabolic acclimation of rice plants challenged with arsenic. Environmental and Experimental Botany, 123, 22-36.

Savant, N. K., Datnoff, L. E., \& Snyder, G. H. (1997). Depletion of plant-available silicon in soils: A possible cause of declining rice yields Communications in Soil Science and Plant Analysis, 28, 1245-1252.

Sistani, K. R., Savant, N. K., \& Reddy, K. C. (1997). Effect of rice hull ash silicon on rice seedling growth. Journal of Plant Nutrition, 20(1), 195-201.

Sommer, M., Kaczorek, D. Kuzyakov, Y., \& Breuer, J. (2006). Silicon pools and fluxes in soils and landscapes - a review. Journal of Plant Nutrition and Soil Science, 169(3), 310-329.

Tsujimoto, Y. Muranaka, S., Saito, K., \& Asai, H. (2014). Limited Sinutrient status of rice plants in relation to plant-available Si of soils, nitrogen fertilizer application, and rice-growing environments across Sub-Saharan Africa. Field Crops Research, 155, 1-9.

Tsvetkova, N. M., Pakhomov, O. Y., Serdyuk, S. M., \& Yakyba, M. S. (2016). Biologichne riznomanittja Ukrajiny. Dnipropetrovs'ka oblast'. Grunty. Metaly u gruntah [Biological diversity of Ukraine. The Dnipropetrovsk region. Soils. Metalls in the soils]. Lira, Dnipropetrovsk (in Ukrainian).

Vivancos, J., Deshmukh, R., Grégoire, C., Rémus-Borel, W., Belzile, F., \& Bélanger, R. R. (2016). Identification and characterization of silicon efflux transporters in horsetail (Equisetum arvense). Journal of Plant Physiology, 200, 82-89.

Voronkov, M. G. (1969). Composes du silicium biologiquement actifs. Organosilicon Chemistry: 2. Plenary lectures presented at the Second International Symposium on Organosilicon Chemistry, 399-416.

Voronkov, M. G. (1974). Advances in the chemistry of biologically active organosilicon compounds. XXIVth International Congress of pure and applied chemistry plenary and main section lectures presented at Hamburg, Federal Republic of Germany, 45-66.

Voronkov, M. G. (1975). Chapter 27. Silicon in Biology and Medicine. Annual Reports in Medicinal Chemistry, 10, 265-273.

Wattean, F., \& Villemin, G. (2001). Ultrastructural study of the blogeochemical cycle of silicon in the soil and litter of atempérate forest. European Journal Soil Science, 52, 385-395.

Yamauchi, M., \& Winslow, M. D. (1989). Effect of silica and magnesium on yield of upland rice in humid tropics. Plant and Soil, 113(2), 265-269. 